\title{
IMMUNITY TO COVID-19 AND ISSUES OF SCREENING FOR SARS-COV-2 ANTIBODIES
}

\author{
Mayanskiy NA $\square$
}

Pirogov Russian National Research Medical University, Moscow, Russia

\begin{abstract}
This paper briefly presents the known data on the immune response to SARS-CoV-2, and also analyzes the possibilities and limitations of serological testing for antibodies that should be accounted for when planning population studies and interpreting their results.
\end{abstract}

Keywords: COVID-19, SARS-CoV-2, immunity, antibodies, screening

Author contribution: Mayanskiy NA — literature analysis, text authoring.

$\triangle$ Correspondence should be addressed: Nikolay A. Mayanskiy

Ostrovityanova, 1, Moscow, 117997; mayanskiy.nikolay@gmail.com

Received: 01.06.2020 Accepted: 15.06.2020 Published online: 23.06.2020

DOI: 10.24075/brsmu.2020.035

\section{ИММУНИТЕТ К COVID-19 И ВОПРОСЫ ПРОВЕДЕНИЯ СКРИНИНГОВЫХ ИССЛЕДОВАНИЙ АНТИТЕЛ K SARS-COV-2}

\author{
Н. А. Маянский
}

Российский национальный исследовательский медицинский университет имени Н. И. Пирогова, Москва, Россия

В работе кратко представлены известные данные об иммунном ответе на SARS-CoV-2, а также проанализированы возможности и ограничения серологического тестирования на антивирусные антитела, которые следует учитывать при планировании популяционных исследований и интерпретации их результатов.

Ключевые слова: COVID-19, SARS-CoV-2, иммунитет, антитела, скрининг

Вклад авторов: Н. А. Маянский - анализ литературы и написание текста.

$\bigotimes$ Для корреспонденции: Николай Андреевич Маянский

ул. Островитянова, д. 1, г. Москва, 117997; mayanskiy.nikolay@gmail.com

Статья получена: 01.06.2020 Статья принята к печати: 15.06.2020 Опубликована онлайн: 23.06.2020

DOI: $10.24075 /$ vrgmu.2020.035

The evolving COVID-19 pandemic caused by the SARS-CoV-2 coronavirus is unprecedented in modern history. SARS-CoV-2 quickly spread throughout the world, affecting over 5 million and causing death of more than 300 thousand people (WHO data as of May 25, 2020) [1]. It dramatically changed the way of life in many countries, threatening further economic shocks. The reaction of scientific community to the pandemic is also distinguished with speed and scope. As soon as they receive papers from authors, world leading journals publish the latest information about the pathogen and its effect on the body, approaches to treatment and principles of curbing the spread of the virus. Such papers allowed developing the tools to detect SARS-CoV-2 RNA and test for its antibodies within the shortest time. This paper briefly overviews the known data on the immune response to SARS-CoV-2, and also analyzes the possibilities and limitations of serological testing for antibodies that should be accounted for when planning population studies and interpreting their results.

\section{SARS-CoV-2 infection immune response}

The information accumulated to date allows a degree of certainty to the statement that the immune response to SARS-CoV-2 infection develops following a typical scenario. In most SARSCoV-2 patients specific antibodies of various classes appear 1-2 weeks after manifestation of the symptoms [2]. One study reports $40-55 \%$ of patients admitted with COVID-19 developing antibodies by days 5 to 7 , with their number reaching $100 \%$ by days 17 to 19 [3]. In these patients, the antibody titer increased 2-4 times throughout the observation period (up to 27 days from the onset of symptoms) with seroconversion, i.e. appearance of specific antibodies, in the background. Other researchers report the average of $10-15$ days as the term of seroconversion in symptomatic SARS-CoV-2 cases [4]. Another important factor is that most COVID-19 patients, including those that had it in a mild form, develop specific functional antibodies capable of neutralizing the virus that make them effectively immune. Two weeks after the onset of symptoms, such antibodies were found in 94\% of COVID-19 patients [5].

Cellular immunity to SARS-CoV-2 is developing in parallel with antibodies thereto. Within 2-4 weeks after infection, the body generates a pool of virus-specific T-lymphocytes [7, 8]. The hypothesis is that CD4- and CD8- T-lymphocytes will reliably protect their carriers from SARS-CoV-2 reinfection if they had no antibodies detected.

At this stage of development of the pandemic, the data available disallow conclusions about the term of persistence of SARS-CoV-2 immunity. The earlier research into seasonal coronaviruses, MERS-CoV and SARS-CoV-1, which are related to SARS-CoV-2, suggests certain ideas. SARS-CoV-1 patients had the IgG concentration remaining high for 4-5 months, then it was gradually decreasing over the course of 2-3 years, although after 2.5 years up to $90 \%$ of those who had SARSCoV-1 retained neutralizing antibodies. The antibody response followed the like path in MERS-CoV patients: those who recovered retained the antibodies for up to 34 months $[4,6]$.

The SARS-CoV-2 reinfection potential question remains open. So far, no confirmed SARS-CoV-2 reinfection cases have been described. A study on primates showed that having been infected with SARS-CoV-2, the body cannot be reinfected with this virus [6]. There are also no SARS-CoV-1 and MERS$\mathrm{CoV}$ reinfection cases described. However, the cases of reinfection with seasonal coronaviruses are quite common, with the conditions brought by them typically being mild acute 
respiratory diseases. Here, reinfection may be associated with a rapid decline of protective immunity or contracting a new serovariation of the virus $[4,6]$.

\section{COVID-19 seroepidemiology}

So far, most COVID-19 seroepidemiology studies have only considered cohorts of patients admitted to the hospitals and patients with symptoms of the infection. It is possible that the bodies of individuals that had the symptoms manifesting minimally or not manifesting at all generate antibodies at a different rate and their post-infection immunity has different properties [9]. Various media outlets report the frequency of asymptomatic (or subclinical) seroconversion in various populations sharing a territory or an occupation, such reports being of varying degrees of reliability. The scientific community has produced a very small amount of publications covering this topic. A serological examination of Los Angeles residents that aimed to assess the cumulative incidence of COVID-19 revealed IgG and/or IgM antibodies in 35 (4.65\%) of 863 participants [10], with 10 (29\%) of the 35 reporting no symptoms of acute respiratory viral infections in the last two months, which could point to seroconversion as a result of asymptomatic SARSCoV-2 infection. The possibility of subclinical seroconversion was demonstrated in a small study showing 3 (23\%) of 13 patients and 11 (44\%) of 25 employees of an outpatient dialysis center in the USA generating anti-SARS-CoV-2 IgM and/or IgG 21 days after contact with a COVID-19 patient. In this study, the majority of participants with antibodies (2 of 3 patients and 9 of 11 employees) had no COVID-19-like symptoms [11].

\section{The problems of anti-SARS-CoV-2 serological testing}

There is no doubt that serological tests for antibodies to SARS-CoV-2 can be extremely useful for diagnosing infection, studying population immunity, evaluating the response to vaccination etc. At the same time, such tests have specific limitations, which should be acknowledged on par with their advantages. A number of materials published in the respected scientific journals $[6,9,12-14]$ recommend caution in the use of anti-SARS-CoV-2 serological tests, most of which are flawed.

Like any serological test, the anti-SARS-CoV-2 test will inevitably produce a certain percentage of erroneous (falsepositive and false-negative) results. Obviously, their number will depend on the analytical capabilities of the test system, such as sensitivity (ability to detect antibody carriers; proportion of truepositive results) and specificity (selectivity of the test; proportion of true-negative results).

The sensitivity and specificity of $90-95 \%$ are often misleading; the figures are interpreted as a guaranteeing a low probability of error, 5-10\%, respectively, which can be simply neglected. However, it should be remembered that the number of false results will vary depending on the prevalence of antibodies in a given population. This fact is often ignored, which leads to an inaccurate interpretation of the results. Below are some cases exemplifying the concern outlined above. Suppose there is a test system with a declared sensitivity and specificity of $95 \%$. It is applied to 1) examine a population of former COVID-19 patients (the expected prevalence of antibodies is 90\%); 2) examine a population not infected with COVID-19 and showing no symptoms of acute respiratory viral infections in the last 2 months (the expected prevalence of antibodies is 5\%). The following formula allows assessing reliability of test result with the help of the positive prognostic value (PPV), i.e. the probability that a positive test result is true-positive [14]:
PPV $=$

Sensitivity $\times$ Prevalence $+(1-$ Specificity $) \times(1-$ Prevalence $)$

For the first population (former COVID-19 patients) the PPV is 0.99 , i.e., the probability that with a positive test result the individual actually has antibodies is $99 \%$. However, the situation looks radically different in the second hypothetical population, for which the PPV value (with the same sensitivity and specificity of the test system) is only $50 \%$. Thus, selectivity of the test system with a specificity of $95 \%$ is insufficient for a population with a low level of occurrence of antibodies; such a system produces false-positive results in half (!) of the cases.

Therefore, the degree of sensitivity and specificity of a test system should be evaluated depending on the characteristics of the population subject to examination, and interpretation of results of the tests should factor in the possible error. Simple calculations show that in order to have PPV > 80\% in a population $5 \%$ of which has antibodies, the test system's specificity must be over $99 \%$.

Currently, the market offers dozens of SARS-CoV-2 antibody test systems from various manufacturers. They are actively promoted, the campaigns' messages declaring accuracy and reliability of testing. Not all manufacturers openly report analytical characteristics of their products; probably, some of them simply have no knowledge of such since they did not set up the studies needed to acquire such information [9]. The use of such unreliable tests during a pandemic can be dangerous both for a specific person and for the population as a whole. The decisions about admission of medical personnel to work, making restrictive measures milder/stricter, as well as stigmatization of "people without antibodies" and, conversely, granting complete indulgence to individuals with SARS-CoV-2 antibodies down to giving them the so-called "immunological passports" based on a single study with uncertain level of confidence, can lead to serious consequences $[9,13]$.

In addition, the scale of serological testing should be reasonable. Testing the entire population is impractical and not necessary. For example, there are detailed guidelines issued by Rospotrebnadzor describing the procedure for organizing and conducting serological monitoring of the status of herd immunity to vaccine-controlled infections [15]. These guidelines describe indicator representative groups that should be tested, the frequency of their examination, etc. The SARS-CoV-2 antibodies screening activities should be clearly planned so that the results obtained in relatively small samples could allow reliable conclusions about herd immunity in the population as a whole and in individual high-risk (medical workers in particular) or vulnerable groups (elderly people, patients with chronic diseases, etc.).

In the view of the stated considerations, the gigantic scale of anti-SARS-CoV-2 population screening launched in May 2020 in Moscow, the effort involving 3 to 6 million people and costing $0.5-1$ billion rubles [16], is bewildering, to say the least. The test system used for this effort has a specificity of $95.38 \%$, which is clearly not enough for use in a population with a low prevalence of antibodies, as mentioned above. With a high degree of certainty, it can be said that Moscow residents, who have been in isolation for almost two months, constitute just such a population. Even if we assume that the real proportion of seropositive individuals is $10 \%$, a test with the indicated specificity will give over $30 \%$ of false-positive results.

\section{CONCLUSIONS}

Mass-scale testing of individuals that did not have COVID-19 (i.e., populations with a low incidence of SARS-CoV-2 
antibodies) can generate a large number of false-positive results, significantly exceeding the number of true-positive results. The sample size for such studies should be reasonably sufficient, and the data interpreted with the systems' analytical characteristics factored in. These characteristics should be publicly available and verifiable. Otherwise, the widespread use of imperfect serological tests can be a source of serious errors in the medical and managerial decisions made.

${ }^{1}$ This value is indicated in the decision of the Moscow Department of Health COVID-19 Clinical Committee of 12.05.2020 (not published officially). Other sources of data on the analytical characteristics of this test system could not be found.

\section{References}

1. WHO: Coronavirus disease (COVID-19). Situation Report 126. Available from: https://www.who.int/docs/default-source/ coronaviruse/situation-reports. Доступ 26 мая 2020.

2. Sethuraman N, Jeremiah SS, Ryo A. Interpreting Diagnostic Tests for SARS-CoV-2. JAMA. 2020 May 6. DOI: 10.1001/ jama.2020.8259.

3. Long QX, Liu BZ, Deng HJ, Wu GC, Deng K, Chen YK, et al. Antibody responses to SARS-CoV-2 in patients with COVID-19. Nat Med. 2020 Apr 29. DOI: 10.1038/s41591-020-0897-1.

4. Kellam P, Barclay W. The dynamics of humoral immune responses following SARS-CoV-2 infection and the potential for reinfection. J Gen Virol. 2020 May 20. DOI: 10.1099/jgv.0.001439.

5. Wu F, Wang A, Liu M, Wang Q, Chen J, Xia S, et al. Neutralizing antibody responses to SARS-CoV-2 in a COVID-19 recovered patient cohort and their implications. Preprint at medRxiv. Available from: https://doi.org/10.1101/2020.03.30.20047365.

6. Kirkcaldy RD, King BA, Brooks JT. COVID-19 and Postinfection Immunity: Limited Evidence, Many Remaining Questions. JAMA. 2020 May 11. DOI: 10.1001/jama.2020.7869.

7. Melgaço JG, Azamor T, Ano Bom APD. Protective immunity after COVID-19 has been questioned: What can we do without SARSCoV-2-IgG detection? Cell Immunol. 2020 Apr 28; 353: 104114. DOI: 10.1016/j.cellimm.2020.104114.

8. Ni L, Ye F, Cheng ML, Feng Y, Deng YQ, Zhao H, et al. Detection of SARS-CoV-2-Specific Humoral and Cellular Immunity in COVID-19 Convalescent Individuals. Immunity. 2020 May 3. DOI: 10.1016/j.immuni.2020.04.023.

\section{Литература}

1. WHO: Coronavirus disease (COVID-19). Situation Report 126. Available from: https://www.who.int/docs/default-source/ coronaviruse/situation-reports. Доступ 26 мая 2020.

2. Sethuraman N, Jeremiah SS, Ryo A. Interpreting Diagnostic Tests for SARS-CoV-2. JAMA. 2020 May 6. DOI: 10.1001/ jama.2020.8259.

3. Long QX, Liu BZ, Deng HJ, Wu GC, Deng K, Chen YK, et al. Antibody responses to SARS-CoV-2 in patients with COVID-19. Nat Med. 2020 Apr 29. DOI: 10.1038/s41591-020-0897-1.

4. Kellam P, Barclay $W$. The dynamics of humoral immune responses following SARS-CoV-2 infection and the potential for reinfection. J Gen Virol. 2020 May 20. DOI: 10.1099/jgv.0.001439.

5. Wu F, Wang A, Liu M, Wang Q, Chen J, Xia S, et al. Neutralizing antibody responses to SARS-CoV-2 in a COVID-19 recovered patient cohort and their implications. Preprint at medRxiv. Available from: https://doi.org/10.1101/2020.03.30.20047365.

6. Kirkcaldy RD, King BA, Brooks JT. COVID-19 and Postinfection Immunity: Limited Evidence, Many Remaining Questions. JAMA. 2020 May 11. DOl: 10.1001/jama.2020.7869.

7. Melgaço JG, Azamor T, Ano Bom APD. Protective immunity after COVID-19 has been questioned: What can we do without SARSCoV-2-IgG detection? Cell Immunol. 2020 Apr 28; 353: 104114. DOI: 10.1016/j.cellimm.2020.104114.

8. Ni L, Ye F, Cheng ML, Feng Y, Deng YQ, Zhao H, et al. Detection of SARS-CoV-2-Specific Humoral and Cellular Immunity in COVID-19 Convalescent Individuals. Immunity. 2020 May 3. DOI: 10.1016/j.immuni.2020.04.023.
9. Torres R, Rinder HM. Double-Edged Spike-Are SARS-CoV-2 Serologic Tests Safe Right Now? Lab Med. 2020 May 6; 51 (3): 236-8. DOI: 10.1093/labmed/Imaa025.

10. Sood N, Simon P, Ebner P, Eichner D, Reynolds J, Bendavid E, et al. Seroprevalence of SARS-CoV-2-Specific Antibodies Among Adults in Los Angeles County, California, on April 10-11, 2020. JAMA. 2020 May 18: e208279. DOI: 10.1001/jama.2020.8279.

11. Hains DS, Schwaderer AL, Carroll AE, Starr MC, Wilson AC, Amanat F, et al. Asymptomatic Seroconversion of Immunoglobulins to SARS-CoV-2 in a Pediatric Dialysis Unit. JAMA. 2020 May 14: e208438. DOI: 10.1001/jama.2020.8438.

12. Ismail AA. Serological tests for COVID-19 antibodies: Limitations must be recognized. Ann Clin Biochem. 2020 May 14: 4563220927053. DOI: 10.1177/0004563220927053.

13. Krammer F, Simon V. Serology assays to manage COVID-19. Science. 2020 May 15: eabc1227. DOI: 10.1126/science. abc1227.

14. Mathur G, Mathur S. Antibody Testing For Covid-19. Am J Clin Pathol. 2020 May 15: aqaa082. DOI: 10.1093/ajcp/aqaa082.

15. Metodicheskie ukazaniay MU 3.1.2943-11 "Organizatsiya b provedenie serologicheskogo monitoring sostoyaniay kollectivnogo immunitets k infectsiyam, upravlyaemym sredstavami spetsificheskoi profilaktiki (difteriya, stolbnyakm koklyush, korj, krasnukha, gepatit B)". Russian.

16. Available from: https://vademec.ru/news/2020/05/25/mgfomsopredelil-stoimost-provedeniya-testa-na-antitela-k-covid-19. Доступ 26 мая 2020

9. Torres R, Rinder HM. Double-Edged Spike-Are SARS-CoV-2 Serologic Tests Safe Right Now? Lab Med. 2020 May 6; 51 (3): 236-8. DOI: 10.1093/labmed/Imaa025.

10. Sood N, Simon P, Ebner P, Eichner D, Reynolds J, Bendavid E, et al. Seroprevalence of SARS-CoV-2-Specific Antibodies Among Adults in Los Angeles County, California, on April 10-11, 2020. JAMA. 2020 May 18: e208279. DOI: 10.1001/jama.2020.8279.

11. Hains DS, Schwaderer AL, Carroll AE, Starr MC, Wilson AC, Amanat F, et al. Asymptomatic Seroconversion of Immunoglobulins to SARS-CoV-2 in a Pediatric Dialysis Unit. JAMA. 2020 May 14: e208438. DOl: 10.1001/jama.2020.8438.

12. Ismail AA. Serological tests for COVID-19 antibodies: Limitations must be recognized. Ann Clin Biochem. 2020 May 14: 4563220927053. DOI: 10.1177/0004563220927053.

13. Krammer F, Simon V. Serology assays to manage COVID-19. Science. 2020 May 15: eabc1227. DOI: 10.1126/science.abc1227.

14. Mathur G, Mathur S. Antibody Testing For Covid-19. Am J Clin Pathol. 2020 May 15: aqaa082. DOI: 10.1093/ajcp/aqaa082.

15. Методические указания МУ 3.1.2943-11 «Организация и проведение серологического мониторинга состояния коллективного иммунитета к инфекциям, управляемым средствами специфической профилактики (дифтерия, столбняк, коклюш, корь, краснуха, эпидемический паротит, полиомиелит, гепатит В)».

16. Available from: https://vademec.ru/news/2020/05/25/mgfomsopredelil-stoimost-provedeniya-testa-na-antitela-k-covid-19. Доступ 26 мая 2020. 